\title{
Osmaniye İlinde Sahipsiz Köpeklerin Rehabilitasyonu ve Viral Enfeksiyon Profilaksisi
}

\author{
Bilge Kaan Tekelioğlu ${ }^{1 *}$, Hacer Burcu Yüceer ${ }^{2 a}$, Bünyamin Akın²b, Özgür Koçc ${ }^{2 c}$ Mehmet Çelik ${ }^{3}$, Sinan \\ Kandır $^{4}$, Ladine Çelik ${ }^{5}$, Mahmut Ali Gökçe ${ }^{6}$
}

\begin{abstract}
1* Çukurova Üniversitesi Ceyhan Veteriner Fakültesi, Viroloji Anabilim Dalı, Adana, Türkiye (ORCID:0000-0001-6727-3175), ktekelioglu@ cu.edu.tr ${ }^{2}$ T.C. Osmaniye Belediyesi, Osmaniye, Türkiye ${ }^{\mathrm{a}}$ (ORCID: 0000-0002-2816-1098), ${ }^{\mathrm{b}}\left(\mathrm{ORCID}\right.$ : 0000-0003-1074-652X), ${ }^{\mathrm{c}}(\mathrm{ORCID}$ : 0000-0002-0594-1198), osmaniyebelediyesi@osmaniye-bld.gov.tr,

${ }^{3}$ Çukurova Üniversitesi Ceyhan Veteriner Fakültesi, Gıda Hijyeni ve Teknolojisi, Adana, Türkiye (ORCID: 0000-0003-4330-2490), mcelik.cu@gmail.com

${ }^{4}$ Çukurova Üniversitesi Ceyhan Veteriner Fakültesi, Fizyoloji Anabilim Dalı, Adana, Türkiye (ORCID: 0000-0002-8404-7994), sinankkandir@cu.edu.tr 5 Çukurova Üniversitesi Ziraat Fakültesi, Zootekni Bölümü, Adana, Türkiye (ORCID: 0000-0003-3352-9181), ladine@ @ cu.edu.tr

${ }^{6}$ Çukurova Üniversitesi Ceyhan Veteriner Fakültesi, Zootekni ve Hayvan Besleme Bölümü, Adana, Türkiye (ORCID: 0000-0002-8716-5996), magokce@ @u.edu.tr
\end{abstract}

(International Conference on Design, Research and Development (RDCONF) 2021 - 15-18December 2021)

(DOI: $10.31590 /$ ejosat.1047514)

ATIF/REFERENCE: Tekelioğlu, B.K., Yüceer, H.B., Akın, B., Koç, Ö., Çelik, M., Kandır, S., Çelik, L., \& Gökçe, M.A. (2021). Osmaniye İlinde Sokak Köpeklerinin Rehabilitasyonu ve Viral Enfeksiyon Proflaksisi. Avrupa Bilim ve Teknoloji Dergisi, (32), 956966.

\section{$\ddot{O} \mathbf{z}$}

Bu çalışma T.C. Osmaniye Belediyesi ve Çukurova Üniversitesi Ceyhan Veteriner Fakültesi tarafından desteklenmiştir. Doğa, Yaban Hayatı Koruma ve Araştırma Derneği projeye katkı sağlamıştır. Amaç 5199 ve 7332 Sayılı Hayvanları Koruma Kanunu ve değişiklikleri ile ilgili yönetmelikler kapsamında, insan, hayvan ve çevre sağlığını iyileştirmeye yönelik olarak kurumların bilimsel ve teknolojik imkanlarından faydalanarak sahipsiz köpeklerin rehabilitasyonu ve viral enfeksiyon proflaksisinin sağlanmasıdır. 12 aylık çalışma kapsamında, Osmaniye ilinde yaşayan 296 sahipsiz köpekten 259'una rehabilitasyon uygulandı. Hastalık görülen 106 köpekten 77 'de $(\% 72,6)$ viral antijen saptandı ve hematolojik ve serolojik muayeneler yapılarak tedavi uygulandı. Köpeklerden 47'sinde (\%44,3) Canine Parvovirüs (CPV), 9'da (\%8,5) Canine Distemper Virüs (CDV),21'de (\%19,8) Canine Coronavirüs (CCoV) ve 11 'de $(10,4)$ CPV ve CCoV koenfeksiyonu saptand. Tüm köpeklere profilaktik ekto- ve endoparaziter tedavi uygulandı. Sağlıklı ve tedavi sonrası iyileşen 255 köpeğe Kuduz, CPV, CDV, Canine Adenovirus Tip-1 ve Tip-2 (CAV-1 ve CAV-2), Canine Parainfluenza Virüs (CPIV-2) ve Leptospira spp. enfeksiyonlarına karşı koruyucu aşılama uyguland1. 36 köpek sahipledirildi, 206'sı kayıtsızdı ve kulak küpesi ile mikroçip takılarak kayıt altına alındı, aktif olan 189'u kısırlaştırıldı ve hepsi bulundukları yere geri bırakıldı. Bu sayede Osmaniye ilinde yaşayan köpeklerde viral enfeksiyon hastalıklarının araştırılması, hasta ve taşıyıcı hayvanların tespiti, tedavisi ve bölgesel enfeksiyon kontrolü için koruyucu aşı çalışması yapıldı. Kuduz hastalığı ölümcül bir zoonotik enfeksiyon olup sahipsiz hayvanların aşılanmaları rutin olarak ülke genelinde yaygın bir uygulamadır ve kanun ve yönetmelikler ile sağlanmaktadır. CPV-2, CDV, CAV-1 ve CAV-2, CPIV-2 ve Leptospira spp. aşıları köpekler için yapılması gerekli aşılardır (Core Vaccines) ancak sahipsiz köpeklerin aşılanması ve mikroçip uygulaması ülkemizde yaygın bir uygulama değildir. Bu çalışma sahipsiz köpeklerin refahının sağlanması açısından bir 'İyi Veteriner Hekimlik ve Hayvan Refahı' uygulamasıdır. Halk, hayvan ve çevre sağlığının iyileştirilmesi açısından bir 'Tek Sağlık' uygulamasıdır. Sonuç: Bu çalışma Osmaniye Belediyesinin "Mutlu Şehir" projesini desteklemiştir. Yerel Yönetim, Üniversite ve Sivil Toplum Kuruluşu işbirliği ile 12 ayda 255 sahipsiz köpeği rehabilite edilerek ve aşılanarak viral enfeksiyon profilaksisi sağlanmıştır.

Anahtar Kelimeler: Aşı, Canine Coronavirus, Canine Distempervirüs, Canine Parvovirüs, Proflaksi, Sahipsiz Köpek. 


\title{
Rehabilitation and Viral Infection Prophylaxis of Stray Dogs in Osmaniye Province
}

\begin{abstract}
This project was supported by Osmaniye Municipality and Çukurova University Ceyhan Veterinary Faculty, with the contribution of Nature, Wildlife Conservation and Research Association. The aim is to maintain human, animal and environmental health within the scope of the Animal Protection Law No. 5199 and 7332 and its amendments, and to provide rehabilitation and viral infection prophylaxis of stray dogs by cooporational scientific and technological resources of the institutions. Within the scope, rehabilitation was applied to 259 stray dogs living in Osmaniye in a 12-month period. Viral antigen was detected in 77 (\%72.6) out of 106 dogs with signs of disease, and hematological and serological examinations were performed and treatment was administered.Of these dogs, 47 (\%44.3) had Canine Parvovirus (CPV-2), 9 (\%8.5) had Canine Distemper Virus (CDV), 21 (19.8) had Canine Coronavirus $(\mathrm{CCoV})$, and 11 (\%10.4) had CPV and CCoV coinfection.All dogs received prophylactic ecto- and endoparasitic treatment.Proflactic vaccination against Rabies, CPV, CDV, Canine Adenovirus Virus (CAV-1 and CAV-2), Canine Parainfluenza Virus (CPIV-2) and Leptospira spp. infections was administered to dogs that were healthy and recovered after treatment.36 dogs were adopted, 206 of them were unregistered and registered with ear tags and microchips, 189 active ones were neutered and all were released back to where they were found.Investigation of major canine viral diseases in Osmaniye province, detection and treatment of sick and carrier animals, and regional infection control preventive effortwere carried out. Rabies is a deadly zoonotic infection and routine vaccination of stray animals against Rabies vaccination is a common practice across the country and is provided by laws and regulations. CPV-2, CDV, CAV-1 and CAV-2, CPIV-2 and Leptospira spp. vaccinations are Core Vaccines for dogs, but vaccination of stray dogs and microchip application is not a common practice.Regarding public and environmental health, it is a 'One Health' practice concerning to prevent viral diseases among stray dog population. Conclusion: This study supported the "Happy City" project of Osmaniye Municipality. 255 stray dogs were rehabilitated in 12 months with the cooperation of the Local Administration, University and NonGovernmental Organization, and viral infection prophylaxis was provided by vaccination.
\end{abstract}

Keywords: Vaccine, Canine Parvovirus, Canine Distempervirus, Canine Coronavirus, Stray Dogs, Prophylaxis.

\section{Giriş}

Köpekler (Canis lupus familiaris) asırlar boyunca neredeyse insanlık tarihi kadar eski bir süreden beridir insanlar ile yakın ilişki içinde olmuşlar vebirlikte yaşamışlardır. Bu birliktelik başlangıçta ve çoğu zaman iş ve çalışma nedenli olsa da aslında temelde karşılıklı ihtiyaçlar birbirine olan güven ve dostluğa dayanmaktadır. Günümüzde köpekler insanların en iyi hayvan dostları olarak tanımlanmaktadır. Küresel köpek popülasyonununyaklaşı 900 milyon olduğu tahmin edilmektedir ve bunların yaklaşık \%20'sininhareket alanları sınırlandırılabilen ve kontrol edilebilen sahipli evcil hayvanlar oldukları kabul edilmektedir [1-3]. Köpeklerin \% 80'inin iseserbest dolaşan köpekler oldukları vehareket alanlarının belirli bir avlu, bahçe, ev ya da alanlasınırlandırılmadıkları bildirilmiştir [4-5] Serbest dolaşan köpekler sahipli veya sahipsiz olabilirler vebüyük çoğunluğusahipsiz köpekleridir, kalan kısım ise köy köpekleri, çoban köpekleri ve vahşi köpekler gibi diğer köpeklerden oluşmaktadır. Bedford [6] ise dünya genelinde 470 milyon evcil köpek ve 370 milyon sahipli kedi olduğunu ve bu sayı içerisinden Avrupa Birliği Ülkelerinde 65 milyon köpek ve 75 milyon kedinin sahipli olduğunu bildirmiştir. Avrupa Birliği içerisinde Almanya'nın 9,5 milyon köpek ile ilk sırada olduğu ve onu İngiltere, Polonya ve Fransa'nın takip ettiği [6] ve Türkiye'de ise yaklaşık 1.220 milyon sahipli köpek olduğu ve bu sayının 2012 y1lında 1.100 milyon iken 2020 y1lına kadar 10,9 artış gösterdiği bildirilmiştir [7].

Kuduz, Canine Coronavirüs (CCoV), Canine Distempervirüs (CDV), Canine Parvovirüs (CPV), Canine Adenovirüs (CAV) ve Canine Parainfluenzavirüs (CPIV)enfeksiyonlarıköpekler arasında yüksek morbidite oranlarına sahip viral enfeksiyonlardır. Bunlar arasında CDV, CPV-2 ve CCoVenfeksiyonlariyüksek insidans ve morbidite ile seyreder veCPV-2 ve CDV ise diğerlerine göre daha yüksek mortalite oranları ile en sık rastlanılan ölümcül köpek hastalıkları olarak ön plana çıkmaktadırlar [8-13].
Kuduz hastalığı insan ve diğer memelileri etkileyen sisinir sistemi ve beyin yangısı oluşturan $\% 100$ ölümcül zoonoz bir hastalık olarak önemini korumaktadır [14]. Kuduz hastalığı virüsü (Rabies Virus) Rhabdoviridae ailesinden, Lyssavirus cinsinde yer alan RNA bir virüs olan Rabies Lyssavirüsüdür. Kuduz hastalığı dünya genelinde, 150 'den fazla ülke ve bölgede görülen, aşı ile önlenebilir bir viral zoonoz hastalıktır. Japonya, İngiltere, İskoçya, İrlanda, Malta, Avustralya, Yeni Zellanda, Belçika, İsveç, Singapur vd. bazı ülkeler hastalığı eradike etmiştir [15]. İnsanlarda görülentüm kuduz vakalarının \%99'uköpekler tarafindandır ve insan kuduz ölümlerinin ana kaynağıdırlar. Köpeklerin aşılanması ve köpek 1sırıklarının önlenmesi yoluyla bulaşmayı durdurmak mümkündür. Enfeksiyon, başta Asya ve Afrika olmak üzere her yıl on binlerce ölüme neden olmaktadır. Küresel olarak kuduz, yılda 8,6 milyar ABD Doları tutarında bir tahmini maliyete neden olmaktadır. Şüpheli kuduz hayvanlar tarafından isırılan kişilerin \%40'1 15 yaşın altındaki çocuklardır. Kuduz olduğundan şüphelenilen bir hayvanla temastan sonra yarayı hemen sabun ve suyla yıkamak çok önemlidir ve hayat kurtarabilir. Birden fazla sektörün katılımı ve toplum eğitimi, farkındalık programları ve aşı kampanyaları dahil'Tek Sağlık' perspektifinde işbirlikleri kritik öneme sahiptir.DSÖ (WHO), "2030 y1lına kadar köpek aracılı kuduzdan sıfır insan ölümü" hedefine doğru ilerleme sağlamak için "Kuduza Karşı Birleşmek" sloganı ile eylemlere öncülük etmektedir [14].

CCoVenfeksiyonlarının önemi ise son yıllarda zoonoz olduğunun anlaşılması ile ve insanlara bulaşarak 8 . İnsan coronavirüs enfeksiyonuna yol açması nedeniyle giderek önem kazanır hale gelmiştir [16-19]. CCoV enfeksiyonlarıyüksek morbidite, düşük mortalite ile seyretmekle birlikte yüksek patojenik varyantları saptanmıştır, ayrıca coronavirüslerin genel karakteristik özelliği gereği mutasyonlar ile virülens değişikliği ve tür atlayabilme yeteneklerine sahiptirler [20-21].Canine coronavirüsler (CCoV) büyük, zarflı, pozitif iplikli RNA virüsleridir. Köpeklerde üç farklı coronavirüs tanımlanmıştır [9, 
21]. Canine coronavirüs $(\mathrm{CCoV})$ tip I ve tip II, grup 1 coronavirüslerinde yer alır ve bunların evrimi, feline coronavirüs (FCoV) tip I ve tip II ile ilişkilidir. CCoV tip I ve FCoV tip I arasında heterolog rekombinasyon ile oluşan FCoV tip II, CCoV tip I ise genetik olarak CCoV tip II'ye göre FCoV tip I'e daha benzerdir [9,21].Ayrıca, kedilerde patojenite açısından farklılık gösteren iki farklı FCoV suşu daha gözlenmiştir. Akut ölümcül hastalığın başlangıcı (kedi enfeksiyöz peritonit), FCoV genomunun 3' ucundaki $3 \mathrm{c}$ ve $7 \mathrm{~b}$ genlerindeki silinmeler veya rekombinasyonlarla enterik FCoV'lerin (organizma boyunca yayılabilen) pantropik varyantlardan kaynaklanmaktadır [22, 23]. Benzer şekilde, domuz ve murin coronavirüslerinde doku tropizmindeki değişiklikler ve yakın zamanda kabul edilen ciddi akut respiratuar sendromhastalığıyla ilişkili coronavirüsün insanlara adaptasyonu benzer mutasyonlar veya silinmeler ile ilişkilendirilmiştir [24,25]. Solunum yolunda saptanan bir üçüncü köpek coronavirüs olan CRCoV'nin, grup 2 coronavirüsleri içinde sığır coronavirüs spike $(\mathrm{S})$ proteininde $<\%$ 96.0 amino asit (aa) konservasyonu vardır ve bu da yeni bir tür atlandığına işaret eden güçlü kanıtlar sağladığı bildirilmiştir [26]. Köpeklerde coronavirüs enfeksiyonu genellikle enterik yolla sınırlıdır. Enfeksiyon kendiliğinden sınırlı klinik bir seyir izler ve genellikle sadece hafif veya asemptomatik enterit formları oluşturur [9,21]. CCoV tip II'nin yüksek patojenik bir varyantı olan pantropik varyant suş tanımlanmıştır [27].

Canine Distempervirüsü (CDV) Paramyxoviridae ailesinin tek iplikli RNA virüsü olan morbilivirüstür. Evcil ve yabani köpek türleri, çakallar, tilkiler, pandalar, kurtlar, yaban gelincikleri, kokarcalar, rakunlar ve büyük kedilerin yanı sıra bazı primatlar ve çeşitli türleri içeren çok farklı hayvanları etkileyen viral bir hastalıktır $[8,10]$. CDV sistemik, solunum yolu, kütanöz ve sinir sistemini doku ve organlarına affinite duyar ve enfeksiyon oluştururlar $[8,10]$. Genç ve yetişkin köpeklerde yüksek morbidite ve mortalite ile seyrederek ekonomik zarar yol açarlar[8,10].

Canine parvoviral enterit en yaygın bulaşıcı ve ölümcül enfeksiyonlardan birisidir. Günümüzdeki inanış kedi panleukopeni virüsünün mutasyona uğrayarak CPV-2'ye dönüşmüş olduğu yönündedir. Parvovirüs çok bulaşıcıdır ve köpekten köpeğe dışkılarıyla doğrudan veya dolaylı temas yoluyla yayılır. Aşılar bu enfeksiyonu önleyebilir, ancak tedavi edilmemiş vakalarda ölüm oranının \%70-90 arasında olduğu, yetişkin köpeklerde ise \%1'den az olarak saptandığı bildirilmiştir [8,28-30]. Köpek parvovirüsü köpekler, tilkiler, kurtlar, kediler ve kokarcalar da dahil olmak üzere diğer memelileri enfekte edebilir; ancak, insanlara bulaşmaz. İki tipi vardır; CPV-1 ve CPV-2. CPV-2 nin ise alt suşları vardır; $2 a, 2 b$ ve $2 c$. CPV-2'nin klinik hastalığı daha yaygındır ve özellikle 6 hafta ile 6 ay arasındaki yaşlarda olan aşılanmamış genç yavrularda ortaya çıkar ve yüksek morbidite ve mortalite ile seyreder [8,28-30].

Canine adenoviruslar Adenoviridae ailesinde yer alırlar. Canine Adenovirus Tip $1(\mathrm{CAV}-1)$ ve Canine Adenovirus Tip 2

(CAV-2) olmak üzere iki tip virüs vardır. CAV-1 infectious canine hepatitis (ICH) ve CAV-2 ise infectious canine laryngotracheitis'e neden olmaktadır ve dünya genelinde rastlanılmaktadır. Yeni doğan ve genç köpekler her iki tip virüse karşı duyarlıdır, yetişkin köpekler genellikle iyi bir prognoz sergilerler ve koruyucu aşıları vardır [11].

Köpek parainfluenza virüsü (CPIV) Rubulavirüs cinsinde yer alan Paramyxoviridae ailesinde yer alan RNA'lı bir virüstür. Köpek öksürüğü olarak da bilinen enfeksiyöz trakeobronşitin en e-ISSN: 2148-2683 yaygın patojenlerinden birisidir veoldukça bulaşıcı bir solunum yolu virüsüdür. Solunum belirtileri köpeklerin grip hastalıklarına (Dog Flu) benzese de, bunlar ilgisiz virüslerdir ve koruma için farklı aşılara gerek duyulmaktadır $[12,13]$.

T.C. Osmaniye Belediyesi "Mutlu Şehir" sloganı ile hizmetlerine devam etmektedir. Hayvan Refahı için çalışmalar ve yatırmlar yapmaktadırve insan, hayvan ve çevre sağlığına hizmet edebilmek için kurumların bilimsel ve teknolojik imkanlarından da faydalanmakta ve ortak projeler yürütmektedir. $\mathrm{Bu}$ kapsamda sorumluluklar çerçevesinde, 5199 ve 7332 Sayılı Hayvanları Koruma Kanunu ve değişiklikleri ile ilgili yönetmelikler kapsamında, sahipsiz köpeklerin rehabilitasyonu T.C. Osmaniye Belediyesi Çeçici Hayvan Barınağı ve Rehabilitasyon Merkezi'nde aralıksız devam etmektedir [31,33].

$\mathrm{Bu}$ çalışmada T.C. Osmaniye Belediyesi, Çukurova Üniversitesi Ceyhan Veteriner Fakültesi'nin bilimsel ve teknolojik imkanlarından da faydalanarak, Osmaniye İli'nde faaliyetlerini sürdüren sivil toplum kuruluşu Doğa, Yaban Hayatı Koruma ve Araştırma Derneği ortaklıkları ile Osmaniye İlinde sahipsiz hayvanlarının rehabilitasyonu ve viral enfeksiyon proflaksisi amaçlanmış ve sağlanmıştır. Bu kapsamda, 12 aylık bir süreçte 255 sahipsiz köpek, rehabilite edilerek zorunlu Kuduz aşının yanı sıra sahipsiz hayvanlar arasında yaygın olarak uygulanmayan Canine Parvovirus (CPV-2), Canine Distemper Virus (CDV), Canine Adenovirus Virus (CAV-1 and CAV-2), Canine Parainfluenza Virus (CPIV-2) ve Leptospira spp. koruyucu aşı uygulamaları ile mikroçip takılarak yapılarak yaşadıkları yerlerine geri bırakılmışlardır. Bu çalışmada T.C. Osmaniye İli'nde köpekler arasında yayılan enfeksiyon hastalıkların araştırılması, hasta ve taşıyıcı olan köpeklerin saptanması, hastaların tedavisi ve aşılama ile köpekler arasında görülen viral enfeksiyonlara karşı bölgesel proflaksi amaçlanmıştır.

\section{Materyal ve Metot}

\section{1. Örnekleme ve Çalışma Alanı}

$\mathrm{Bu}$ çalışma T.C. Osmaniye Belediyesi, Çukurova Üniversitesi Ceyhan Veteriner Fakültesi ve Osmaniye İli'nde faaliyetlerini sürdüren sivil toplum kuruluşu Doğa, Yaban Hayatı Koruma ve Araştırma Derneği ortaklıklarında yürütülen proje kapsamında yürütülmüştür. Osmaniye İl sınırlarında yaşayan sahipsiz köpekler odak noktası olmuştur. Belediye ekiplerinin rutin çalışmaları, kamu kurumları ve görevlilerive vatandaşlardan gelen bilgi ve başvurular ile Dernek çalışmaları sırasında çeşitli nedenlerle rehabilitasyona ihtiyacı olduğu saptanan sahipsiz köpekler belirlenmiştir. Bu kapsamda OcakAralık 2017 arasındaki tarihlerinde 296 sahipsiz köpek belirlenmiştir. Köpeklerin eşkalleri, sağlık durumları, hastalık bulguları, kulak küpesi varlığı ile kayıtlılık durumları tespit edilmiştir.

\subsection{Hematolojik Muayene}

Klinik muayene sırasında hastalık belirtisi gösteren 106 köpeğe hematolojik testler uygulanmıştır. $\mathrm{Bu}$ amaçla köpeklerden sakinliğine ve uygunluk durumuna göre jugular ve sefalik venadan tam kan sayımı, hematokrit muayenesi ve lam frotileri preparatları için EDTA'lı tüplere $5 \mathrm{ml}$. kan örnekleri alınmış ve soğuk zincirde muhafaza edilmiştirtir. Kan örnekleri hemogram (hematokrit ve hemoglobin oranları, eritrosit, platelet, lökosit ve 
diferansiyel lökosit sayıları) analizleri Veteriner Spesifik Otoanilizörü (Mindray BC-5300, Çin) ve kitleri kullanılarak aynı gün içerisinde yapılmıştır. Hematokrit ölçümleri de hematokrit santrfüjü (Nüve NF048) kullanılarak yapılmıştır. Tam kan sayımı sonrası lökosit, lenfosit, granulosit, monosit, eritrosit, hemoglobin, hematokrit ve trombosit sayımları yapılmıştır. Lam frotileri may grünwald-gimza karışık boyama yöntemi kullanılarak boyanmış ve hematoloji sonuçlarının kontrolü için mikroskobik muayene yapılmıştır. Diferansiyel lökosit oranları için sürme kan frotileri pappenheim'ın panoptik boyama yöntemi ile hazırlanmıştır. Bunun için, may grünwald-giemsa boyamaları yapılarak havada kurutulmuş frotiler analize hazır hale getirilerek, 1şık mikroskobu altında (Primo Star, Zeiss, Almanya) immersiyon yağı damlatılarak 100x büyütme ile nötrofil, eozinofil, bazofil, lenfosit ve monosit yüzde oranları belirlenmiştir. Aynı zamanda, viral etkenlerin lenfositler üzerinde olası etkileri (inklüzyon cisimcikleri vb.) için de gözlemsel analizler yapılmıştır. Tedavi sonrası iyileşen köpeklerden 15. gün tekrar örnekleme yapılarak hematolojik testler tekrar edilmiştir ve sağlık yönünden aşıya uygunlukları kontrol edilmiştir.

\subsection{Seroloji}

259 köpek Klinik muayene Hasta köpeklerden Canine Parvovirus (CPV) ve Canine Coronavirus (CCoV) antijenlerini (Ag) saptamak için rektal sürüntü ile dışkı örnekleri ve Canine Distempervirus (CDV) antijenlerini saptamak için sürüntü ile gözyaş1 örnekleri toplanmıştır. Toplanan örnekler lateral immunokramotografi yöntemi ile incelenmiştir. CPV Ag ve CCoV Ag test kitleri (Fassisi ParCo, Fassisi Almanya) ve CDV AG (Anigen CDV Ag, BIONOTE, Güney Kore) ticari firmalardan temin edilmiştir. Üreticilerinin verdiği bilgilere göre testler yüksek duyarlıklık ve özgünlüktedir. CPV Ag testinin 93,33\% duyarl1lık ve 99,99\% özgünlükte, CCoV Ag testinin $99,99 \%$ duyarl1l1k ve $97,50 \%$ özgünlükte ve CDV AG testinin de Nested PCR'a göre 98,98\% duyarlılık ve 97,7\% özgünlükte olduğu bildirilmiştir. Toplanan örnekler kullanım klavuzunda belirtildiği gibi üreticilerinin talimatlarına uyularak hasta başında incelenmiştir.

\subsection{Rehabilitasyon}

Geçici barınağa getirilen köpekler 10 gün karantina kafeslerinde tutulmuşlardır. $\mathrm{Bu}$ sürede hastalık saptanan köpekler klinik, hematolojik ve serolojik olarak muayene edilmiş ve izole edilerek tedavi edilmişlerdir. Küpesi olmayanlar kulak küpelemesi ile kayıt altına alınmışlardır ve tüm köpeklere iyi bakım ve besleme ile ekto- ve endoparaziter uygulama yapılmıştır. Karantina süresi sonrası sağlıklı olan köpeklerden aktif olanlara kısırlaştırma yapılmış, sahiplendirme çalışmaları devam etmiş ve köpekler barınaktan ayrılmadan önce Mikroçip takılarak elektronik kimliklendirme yapılmıştır.

\subsection{Proflaksi}

Klinik, hematolojik ve serolojik muayueneler sonrası sağlıklı ve iyi kondüsyonda oldukları belirlenen ve aşılanmaya uygun bulunan 6 hafta ve üzeri yaşta 255 köpeğe 5 hastalığa karşı proflaktik polivalan dondurularak kurtulmuş (freze-dried) modifiye canlı virüs ve bakterin aşısıuygulanmıştır ve ticari bir firmadan temin edilmiştir (Zoetis Vanguard 5 L4). Polivalan aş1: Canine Parvovirüsü (CPV) ve CPV-2c'nin neden olduğu köpek kanlı ishal hastalığı, Canine Distemper Virüsünün (CDV) neden olduğu köpek gençlik hastalığı, Canine Adenovirüs Tip-1'in (CAV-1) neden olduğu enfeksiyöz köpek hepatiti (ICH), Canine Adenovirüs Tip-2'nin (CAV-2) neden olduğu köpeklerin solunum e-ISSN: 2148-2683 yolu hastalığı, Canine Parainfluenza Virüsünün (CPIV) neden olduğu köpek öksürüğü olarak da bilinen enfeksiyöz trakeobronşit hastalıklarının aşı suşlarının modifiye canlı virüslerini ve ilave olarak Leptospira canicola, L. grippotyphosa, L. Pomona ve L. Icterohaemorrhagiae serovarlarını içeren leptospirosis bakterininden oluşmaktadır. Aşının içeriğinde bulunan viral antijenlerin performanslarının etkinliği retrospektif serolojik çalışmalara dayalı olarak bildirilmiştir. Aşılar 3 hafta arayla 2 doz kas içi (IM) enjeksiyonla uygulanmıştır [34-36]. Kuduz aşısı hücre kültüründen hazırlanan inaktive kuduz virüsü ile formüle edilmiş monovalanbir aşı olup ticari bir firmadan temin edilmiştir(Zoetis Defensor 3). Aşının üretici firma tarafindan Louis Pasteur'ün orijinal 1882 izolatından elde edilen ve kontamine edici ajanlardan arındırılmış olup olmadığ kapsamlı bir şekilde test edilmiş, yüksek oranda immünojenik, sabit bir kuduz virüsü suşu içerdiği bildirilmiştir. Aşıların uygulanmasında üretici firmanın kullanım klavuzunda belirttiği talimatalar uyulmuştur. Aşı 3 ay ve daha yaşlı sağlıklı köpeklere tek doz olarak kas içine (IM) enjeksiyonla uygulanmıştır.

\section{Araştırma Sonuçları ve Tartışma}

\section{1. Örneklem ve Çalışma Alanı Bulguları}

Bu kapsamda Ocak-Aralık 2017 döneminde 296 sahipsiz köpek belirlenmiştir. 106 köpekte ishal, kusma, ateş $\left(>39^{\circ} \mathrm{C}\right)$, üst solunum yolu enfeksiyonu (ÜSY), göz ve burun akıntısı, kaşeksi/zayıf kondüsyon, sinir sitemi bozukluğu (SS), felç, kene, pire ve intestinal parazit enfestasyonu, deri lezyonları, yaralar saptanmıştır. 259 köpek yaşamış 37'si ölmüştür. Detaylı bilgiler Tablo 1 ile Tablo 3-6'da verilmiştir.

Tablo 1. Rehabilitasyon ve proflaksi uygulanan köpekler ve yapılan uygulamalarin detaylı bilgileri.

\begin{tabular}{|c|c|c|c|}
\hline Tür Adı & \multicolumn{3}{|c|}{ Köpek } \\
\hline & E & D & T \\
\hline Belirlenen Hayvan Sayısı & 164 & 132 & 296 \\
\hline Küpeli Hayvan Sayısı & 27 & 22 & 53 \\
\hline Uygulanan Kulak Küpesi Sayısı & 114 & 92 & 206 \\
\hline Uygulanan Mikroçip Sayısı & 114 & 92 & 206 \\
\hline Test Sayısı & 62 & 44 & 106 \\
\hline Aşılama Sayısı & 137 & 118 & 255 \\
\hline Paraziter Uygulama Sayısı & 215 & 185 & 400 \\
\hline Kisırlaştırma Sayısı & 100 & 89 & 189 \\
\hline Sahiplendirme Sayısı & 18 & 18 & 36 \\
\hline
\end{tabular}

\subsection{Hematoloji Sonuçları}

Hasta köpeklerden hazırlanan lam frotilerinin incelenmesi sonrası incelenen örneklerde yaygın olarak ve hematolojik bulgular ile uyumlu şekilde tedavi öncesi 0 . gün lenfopeni ve nötrofiler infiltrasyon gözlemlenmiştir. Ayrıca viral enfeksiyon ile uyumlu bir şekilde nötrofiller içerisinde inklüzyon cisimciklerinin varlığı saptanmıştır (Şekil 1).Tedavi sonrası iyileşen köpeklerden 15. günde alınan ikinci örneklerden yapılan incelemelerde ise yaygın monosit infiltrasyonu gözlemlenmiştir. İyileşen köpeklerden hematolojik verilerin desteklediği klinik bulgularla sağlıklı oldukları saptanan köpeklere aşı uygulanmıştır. 


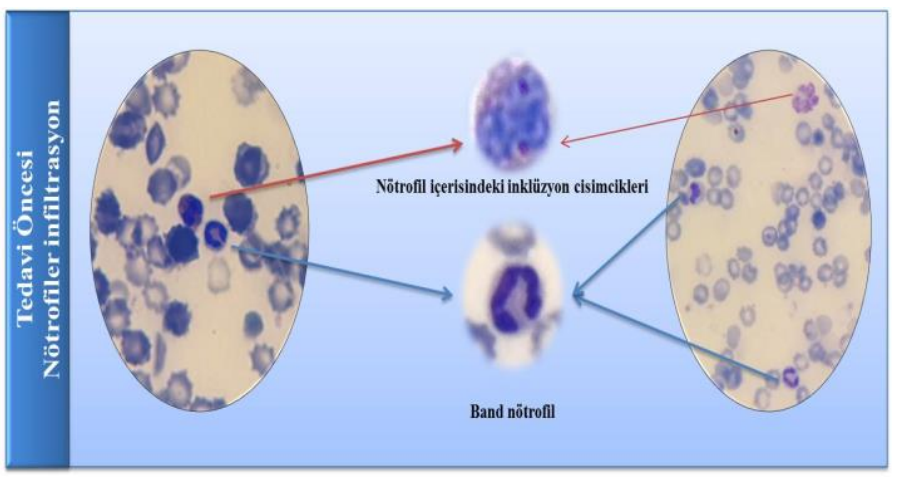

Şekil 1. Sürme kan frotisi görüntüsü (MGG). Tedavi öncesi lenfopeni ve nötrofiler filtrasyon (geniş saha, 100x), band nötrofil (mavi oklar) sayısında artış ile nötrofillerin içerisinde inklüzyon cisimcikleri (kırmızı oklar) görülmektedir.

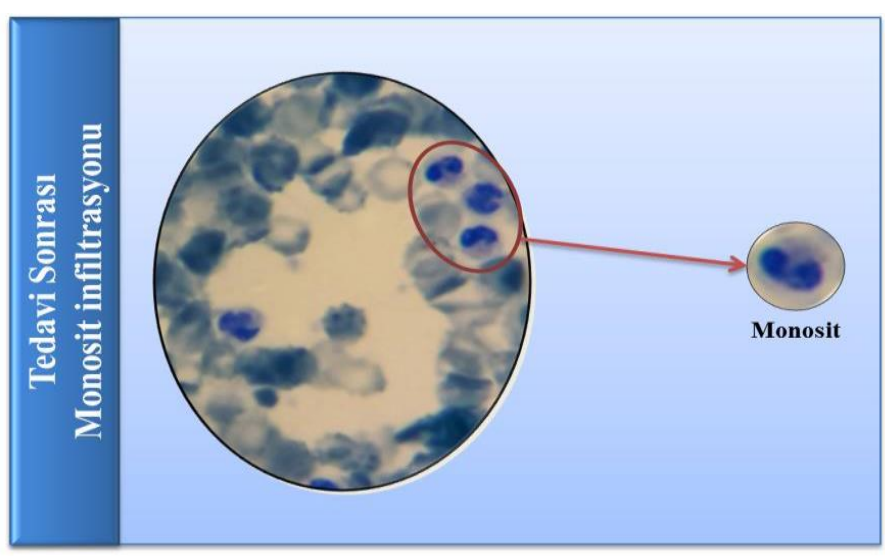

Şekil 2. Tedavi sonrası sürme kan frotilerinde monosit infiltrasyonu (MGG).

\subsection{Seroloji Sonuçları}

296 köpek çalışmaya dahil olmuştur. Testlerin sonuçları, negatif kontrol için tek bant, CDV pozitif test için bir kontrol ve diğeri test olmak üzere çift bant ve $\mathrm{CPV} / \mathrm{CCoV}$ üç bant görsel olarak gözlemlenerek 10 dakika içinde yorumlanmıştır. Testin düzgün çalıştığını göstermek için sonuç penceresinin sol bölümünde kontrol bandı (C) olarak bilinen bir renk bandı görünmesi gerekmektedir. Sonuç penceresinin sağ bölümü test sonuçlarını gösterir. Sonuç penceresinin sağ tarafında başka bir renk bandı belirirse, bu bant test bandıdır (T). Sonuç penceresinde yalnızca bir bandın bulunması, olumsuz bir sonucu gösterir. Sonuç penceresinde iki renk bandının ( $T$ ve $C$ ) bulunması, hangi bandın önce göründüğüne bakılmaksızın, pozitif bir sonucu gösterir. Zayıf bant oluşumu üreticinin tavsiyesiyle pozitif kabul edilmiştir. Test yapıldıktan sonra sonuç penceresinde mor renk bandı görünmüyorsa sonuç geçersiz kabul edilmiştir (Şekil 3). Sonuçlar Tablo 3-6'daverilmiştir. CPV, CCoV ve CDV prevalansı sirasiyla $\% 44,3, \% 19,8$ ve $\% 8,5$ olarak saptanmıştır. Köpeklerin 11 'de $(\% 10,4) \mathrm{CPV}$ ve $\mathrm{CCoV}$ koenfeksiyonu saptanmıştır.

A

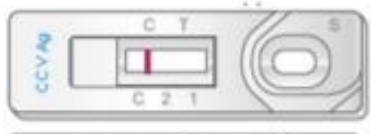

B

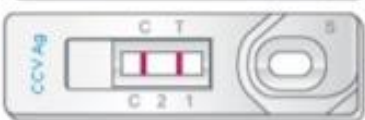

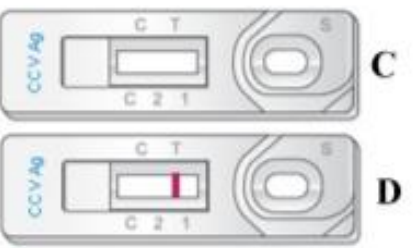

Şekil 3. Testlerin yorumlanmasının ilustrasyonu; (A) Negatif sonuç, (B) Pozitif sonuç, (C ve D) Geçersiz sonuç (Yoon vd.'den adapte edilmiştir [16])

Tablo 3. Serolojik Bulgular; Canine Parvovirüs

\begin{tabular}{|l|c|c|c|c|c|}
\hline & Pozitif + & Negatif & +Dişi & +Erkek & Ölüm \\
\hline CPV & 47 & 59 & 21 & 26 & 32 \\
\hline Oran \% & $\% 44,3$ & 55,7 & $\% 44,7$ & $\% 55,3$ & $\% 68,1$ \\
\hline CPV/CCoV & $11(\% 14,3)$ & 95 & 5 & 6 & 8 \\
\hline Yaş < 3 ay & 26 & 32 & 11 & 15 & 20 \\
\hline 3-5 ay & 12 & 15 & 6 & 6 & 8 \\
\hline 6-12 ay & 5 & 8 & 2 & 3 & 3 \\
\hline$>1$ yaş & 4 & 4 & 2 & 2 & 1 \\
\hline
\end{tabular}

Tablo 4. Serolojik Bulgular; Canine Coronavirüs

\begin{tabular}{|l|c|c|c|c|c|}
\hline & Pozitif + & Negatif & +Dişi & +Erkek & Ölüm \\
\hline $\mathrm{CCoV}$ & 21 & 85 & 9 & 12 & 8 \\
\hline Oran \% & $\% 19,8$ & $\% 80,2$ & $\% 43$ & $\% 57$ & $\% 38$ \\
\hline CPV/CCoV & $11(\% 14,3)$ & 95 & 5 & 6 & 8 \\
\hline Yaş $<3$ ay & 12 & 43 & 5 & 7 & 6 \\
\hline 3-5 ay & 5 & 24 & 2 & 3 & 2 \\
\hline 6-12 ay & 1 & 10 & 0 & 1 & 0 \\
\hline 1 yaş üzeri & 3 & 8 & 2 & 1 & 0 \\
\hline
\end{tabular}

Tablo 5. Serolojik Bulgular; Canine Distemper Virüs

\begin{tabular}{|l|c|c|c|c|c|}
\hline & Pozitif + & Negatif & +Dişi & +Erkek & Ölüm \\
\hline CDV & 9 & 97 & 4 & 5 & 5 \\
\hline Oran \% & $\% 8,5$ & $\% 91,5$ & $\% 44$ & $\% 56$ & $\% 56$ \\
\hline Yaş $<3$ ay & 5 & 38 & 2 & 3 & 4 \\
\hline 3-5 ay & 2 & 26 & 1 & 1 & 1 \\
\hline 6-12 ay & 1 & 13 & 1 & 0 & 0 \\
\hline 1 yaş üzeri & 1 & 10 & 0 & 1 & 0 \\
\hline
\end{tabular}

Tablo 6. Köpeklerin muayene bulgularl

\begin{tabular}{|c|c|c|c|c|c|c|c|}
\hline Oran & İshal & Kusma & Ateş & ÜSY & $\begin{array}{c}\text { Deri } \\
\text { Enf }\end{array}$ & $\begin{array}{c}\text { Zayıf } \\
\text { Kondüsyon }\end{array}$ & SS/Felç \\
\hline $\mathrm{n}$ & 94 & 67 & 75 & 31 & 43 & 98 & 9 \\
\hline$\%$ & $\% 89$ & $\% 64$ & $\% 71$ & $\% 29$ & $\% 34$ & $\% 92$ & $\% 8$ \\
\hline
\end{tabular}

Çalışma sırasında hasta oldukları belirlenen tüm hasta köpeklere deneyimli veteriner hekimler tarafından en üst düzeyde tedavi, iyi bakım ve beslenme uygulanmıştır. CPV, CDV ve CCoV ile enfekte köpeklerde virüsü öldürecek özel bir ilaç mevcut değildir ve tedavi, köpeğin bağışıklık sistemi viral enfeksiyonla savaşana kadar köpeğin vücut sistemlerini desteklemeyi amaçlamıştır. Tedavilere hemen başlanmış ve öncelikle elektrolit, protein ve sivi kayıplarının yerine konarak dehidrasyonla mücadele, kusma ve ishali kontrol altına alma ve ikincil enfeksiyonları önlemeye yönelik yoğun bakım çabalarından oluşmuştur. Hasta köpekler sıcak tutulmuş ve iyi ve temzi bakılmışlardır. CPV ve CDV enfeksiyonlarında tüm uğraş ve agresif tedaviye rağmen köpek ölebilir. Başarılı sonuçlarda erken tanı ve agresif tedavi çok önemlidir. Tamamen iyileşene kadar rehabilitasyona devam edilmiştir. Parvovirüs oldukça bulaşıcı olduğundan, enfeksiyonun yayılmasını en aza indirmek için enfekte köpeklerin izolasyonu sağlanmış ve Parvovirüsün yayılmasını kontrol etmek için kontamine köpek kulübelerinin ve enfekte köpeklerin barındığı ya tutulduğu diğer alanlar deterjan ve tazyikli suyla mekanik yöntemle uygun şekilde temizlenerekdevamında \%5 Sodyum Hipoklorit ile dezenfekte edilmiştir.

\subsection{Rehabilitasyon ve Proflaksi Bulguları}


Yapılan tüm uygulamalar Tablo 1'de verilmiştir. Dünya Küçük Hayvan Veteriner Hekimleri Derneği (WSAVA) ve Türkiye Küçük Hayvan Derneği (KHVHD) köpeklerin Aş1 Rehberi'ni yayınlamışlardır. Rehberde yer alan mutlaka yapılması gereken aşılar (Core Vaccines) mevcut bilimsel ortak görüşe göre, dünya genelinde yayılımı olan, zoonoz, çok bulaşıc1, şiddetli enfeksiyonlara yol açabilen ve köpekler ve insanlarda hayati tehlike oluşturan hastalıklardan korumak için core aşıların tüm hayvanlara uygulanması gerektiği yönündedir. Yapılması zorunlu olmayan aşılar (Noncore Vaccines) ise yaşanılan ya da seyahat edilen bölgeye göre uygulanan aşılardır. Noncore aşılar bölgelere göre farklılıklar gösterebilirler. Noncore aşılar bölgesel farklılıklar, enfeksiyöz hastalıkların prevalansı ve serbest gezen köpek ve kedi popülasyonu dikkate alınarak, bazı ülke ya da bölgelerde WSAVA core aşılar grubuna dahil edilebilmektedir. Önerilmeyen aşılar; WSAVA tarafindan hazırlanan rehberde kullanımlarını gerekçelendirecek yeterli bilimsel kanıtın bulunmadığı durumlarda bazı aşılar, önerilmeyen aşılar olarak sınıflandırılmıştır (Tablo 7). Bakteriyel core aşılarının ise yıllık tekrarlarının yapılması gereklidir [34]. Önceki yıllarda Ülkemizde klavuz niteliğinde herhangi bir yönlendirici bilgi bulunmamaktadır.

\section{Tablo 7: Köpeklerin core ve noncore aşıları (KHVHD;2018)}

\subsubsection{Aşıların Uygulanması}

Aşıların uygulanması sırasında yavru köpeklerin maternal antikorların (MDA) varlığı dikkate alınmıştır. Erken dönemde köpek yavrularına uygulanan aşıların birçoğunun etkinliğinin maternal antikorlar tarafından önemli ölçüde engellendiği bilinmektedir. MDA düzeyi pek çok kritere bağlı olarak yavrular arasında önemli değişkenlikler gösterebilmektedir. Bu nedenle 6 haftadan daha genç yaşta olan köpek yavrularına aşı uygulanmamıştır. 2. dozlar 3 hafta sonra uygulanmıştır [35-39].

$\mathrm{Bu}$ süre, deneysel kanıtlara dayalıdır ve virülent enfeksiyöz ajana maruz bırakılan bir hayvanın ne kadar süre boyunca enfeksiyondan veya hastalıktan korunduğunun belirlenmesi durumunu simgeler. Yakın geçmişte Core Aşılarının çoğunun 1 yıllık minimum koruma sürelerine (DOI'ye) sahip oldukları bildirilmekteydi, bu anlamda aşılamanın her yıl tekrarlanması öneriliyordu. Son yıllarda, aynı ürünlerin çoğunun, minimum 3 yıl boyunca koruduğu belirlendiğinden dolayı bu ürünler 3 yıllık ve üzeri DOI için lisanslandırılmış durumdadırlar. 3 yıllık bir lisansın bile core aşılar için minimum DOI olduğu ve çoğu core aşı için gerçek DOI'nın önemli ölçüde daha uzun olabileceği yapılan çalışmalar temelinde saptanmış bulunmaktadır. Bakteriyel core aşıların yıllık tekrarlarının yapılması gereklidir. Her 3 yılda bir core MLV aşısı uygulanan bir köpek aynı aşının her yıl uygulandığı bir diğeri ile karşılaştırıldığında antikor seviyeleri arasında bir farklılık bulunmadığı ve bu nedenler aynı derecede korunmakta oldukları belirlenmiştir [35-37]. Üretilen farklı aşılar ticari olarak temin edilebilmektedir [38,39].

Parvovirüs enfeksiyonundan kurtulan bir köpek yavrusunun güçlü bir bağışıklığa sahip olması beklenebilir. $\mathrm{Bu}$, enfeksiyondan 20 ay sonrasına kadar test edilmiştir ve bağışıklığın ömür boyu olduğuna inanılmaktadır; $\mathrm{Bu}$ kanıtlanmadığından, aşılamaya devam edilmesi yaygın olarak tavsiye edilir. CPV geçirilmiş enfeksiyonuköpeklerde muhtemelen ömür boyu korunma sağlamaktadır [40].

$\mathrm{CDV}$, solunum, gastrointestinal ve sinir sistemlerine saldıran bir virüsün neden olduğu oldukça bulaşıcı, genellikle ölümcül bir hastalıktır. Yakın zamanda enfekte olmuş hayvanlar arasındaki temas, virüsü bir popülasyonda tutar ve sürekli bir yavru köpek varlığı, enfeksiyona duyarlı bir popülasyon sağlamaya yardımcı olur. Geçirilmiş CDV enfeksiyonu köpeklerde uzun süreli veya ömür boyu sürebilen bağışıklık geliştirdiği bildirilmiştir [10].

Gerek CPV ve gerekse CDV nedenli geçirilmiş enfeksiyona bağlı gelişmiş bağışıklığa sahip köpeklerin korunması gereken Kuduz, CDV, CAV-1 ve CAV-2, CPIV gibi başka virüsler de vardır. CPV ve CDV enfeksiyonu sonrası iyileşen köpekler, iyileşme süresini tamamladıktan sonra (1-4 hafta) normal bir yaşama dönebilirler ve aşılanabilirler [10, 40].Barınaktaki 255 köpek, aralarında $32 \mathrm{CPV}$ ve $5 \mathrm{CDV}$ geçirilmiş enfeksiyonu olanlar da dahil olmak üzere aşılanmışlardır. 4 köpek ise aşılanmaya uygun yaş ve sağlıkta olmadıkları için aşılanmamışlardır.

Felidae familyasında bulunan ve kedigiller familyasının yabani üyelerinin yanı sıra evcil kedilerin de dahil olduğu kedilerinCDV enfeksiyonuna karşı duyarlı oldukları ve hastalığın prevalansı bildirilmiştir. Hem büyük hem de evcil kedilerin, genellikle köpeklerle aynı ortamlarda barınmaları nedeniyle enfeksiyon kapabildikleri bilinmektedir [41]. Sahipsiz köpeklerin CDV aşısı ile korunmaları kediler içinde koruma

\begin{tabular}{|l|l|l|}
\hline $\begin{array}{c}\text { Yapılması } \\
\text { Gereken Aşılar } \\
\text { (Core Vaccines) }\end{array}$ & $\begin{array}{c}\text { Yapılması Zorunlu } \\
\text { Olmayan Aşılar } \\
\text { Noncore Vaccines }\end{array}$ & $\begin{array}{c}\text { Önerilmeyen } \\
\text { Aşılar }\end{array}$ \\
\hline Kuduz & Lyme borrelia & $\begin{array}{l}\text { Canine enteric } \\
\text { coronavirus }\end{array}$ \\
\hline CDV & & \\
\hline CPV-2 & & \\
\hline CAV & & \\
\hline $\begin{array}{l}\text { Canine } \\
\text { Parainfluenza } \\
\text { virüs }\end{array}$ & & \\
\hline Leptospira & & \\
\hline $\begin{array}{l}\text { Bordetella } \\
\text { bronchiseptica }\end{array}$ & & \\
\hline
\end{tabular}

sağlamaktadır.

Adenovirüslerin (AdV) insanlar ve insan olmayan primat, yarasa, kedi, domuz, köpek, koyun ve keçi arasındaki konakçı tür bariyerlerini geçtiği belgelenmiştir. Bulgular, AdV'lerin daha önce sahip olduğunu ve konakçı tür engellerini geçmeye devam edeceğini gösteren önemli kanıtlar göstermektedir ve yeni patojen ortaya çıkması ve salgın olasılığı sonuçları vardır. AdV'lerin zoonotik bulaşması için kanıt sağladığı belirlenen çalışmaların çoğu, türlerin insanlarla insan olmayan primatlar arasında geçiş yaptığını bildirmiştir [42].Sahipsiz köpeklerin CAV-1 ve CAV-2 aşısı olmaları AdV'lerin köpek populasyonu arasında yayılmasını kontrol altına almaktadır.

Köpeklerde enfeksiyöz solunum yolu hastalığına neden olan virüsler genellikle zoonotik olarak kabul edilmez. Köpek parainfluenza ve reovirüsler potansiyel zoonozları temsil eder, ancak bunun önemi bilinmemektedir [43]. Sahipsiz köpeklerin CPIV aşısı olmaları enefeksiyonun yayılmasını kontrol altına almaktadir.

Leptospirosis zoonotik bir hastalıktır ve köpeklerde çok çeşitli klinik tablolara sahiptir. Köpeklerher yaşta, cins veya cinsiyette leptospirosise karşı hassastır. Köpek leptospirozu, büyük cins köpekler, erkek köpekler veya ağırlıklı olarak sahipsiz ya da serbest gezen sahip köpeklerle sinırlı 
değildir.[44].Köpek enfeksiyonlarının çoğunda gerçek enfekte serovar bilinmemektedir. Bununla birlikte, köpeklerde hastalığa neden olan serovarların yerel vahşi yaşamda dolaşan serovarlar olması muhtemeldir. Sahipsiz köpeklerin Leptospira spp. aşısı olmaları köpek sağlığının yanı sıra halk ve çevre sağlığı açısından önemlidir.

Paraziter enfestasyon ve enfeksiyonlar ile mücadele zoonoz riski olabilen özellikle vektörle bulaşan enfeksiyonların önlenebilmesi için diğer önemli bir mücadele yöntemidir. Bu hastalıklar arasında keneler yoluyla bulaşabilen Lyme (Borellia burgdorferi), kum sinekleri ile bulaşan Leismaniasis (Leishmania spp.), kist hidatik (Echinococcus spp) enfeksiyonları ön plana çıkmaktadır. Ecinococcus spp. (Kist Hidatik Hastalığı) ve bazı bağırsak parazitleri köpeklerden insanlara geçebilen başlica parazitlerdir. Kist hidatik, Ecinococcu sspp.'nin neden olduğu ve halk arasında köpek tenyası kisti olarak bilinen paraziter kökeknli zoonoz bir hastalıktır. Ülkemizde 10 bin kişide 1 görülme yaygınlığ 1 dünya ortalamasının üstünde olarak bildirilmiştir. Köpek, kurt, tilki gibi et yiyen hayvanlar bulaşmada önemlidir. Ülkemizde köpeklerin ana bulaşma kaynağı oldukları bildirilmiştir. Parazit köpeğin barsaklarında yaşar veyumurtaları dışkı yoluyla saçılarak çevreye yayılır. Yumurtalar dış ortam koşullarına dayanıklıdır ve1 yıl kadar yaşayabilirler ve arazi eğimi, rüzgâr, yağmur suyu gibi çevresel etkenlerle yayılırlar. İnsanlar ara konakçılar olup bu parazitleri iyi yıkanmamış çiğ sebze ve meyveler yoluyla veya kirli içme sularından alırlar. Alınan yumurtalar bağırsaklara gelir, buradan kan veya lenf yoluyla sıklık sırasına göre karaciğer, akciğer ve diğer organlara yayllarak kist formunda yaşamlarını sürdürür. Organlara yerleşen kistler başlangıçta küçük olduklarından uzun bir süre belirti vermeden seyredebilir. Ancak büyüdükçe sağlık sorunlarınıda beraberinde getirirler [45, 46]. Paraziter hastalılar ile temas etmiş ve taşıyıcı hayvanlarda aşılamalarda istenilen bağışıklık düzeyleri de sağlanamadığı ve hayvanların enfeksiyonlara karşı korunamadığ olmaya devam ettikleri bilinmektedir. $\mathrm{Bu}$ nedenle çalışmaya dahil edilen tüm köpeklere 10 günlük karantina dönemlerinde köpek sağlığının yanı sıra halk ve çevre sağlığı amacıylaendove ektoparaziter sağaltım uygulanmıştır.

Kuduz aşısı uygulaması ilgili kanun ve yönetmelikler ile düzenlenmiştir ve tüm sahipli ya da sahipsiz köpeklerin 3. Aydan itibaren aşılanması ve yılda 1 defa bu aşının tekrar edilmesi zorunluluk olarak belirlenmiştir. Aşılanan hayvanlar kayıt altına alınır, sahipli hayvanlardan sahipleri, sahipsiz hayvanlardan ise şehirlerde Belediyeler köylerde Muhtarlar sorumludur [47, 48]. CPV, CDV, CAV-1 ve CAV-2, CPIV ve Leptospira spp. aşıları KHVHD Ulusal Aşı Rehberi ile WASAVA Aşı Rehberinde mutlaka yapılması gereken aşılar arasında yer almaktadır [34,49,50]. Canine Enteric Coronavirüs (CECoV) aşısı WASAVA [49] ve KHVHD ve [34] 2018 Aş1 Rehberinde Yapılması Önerilmeyen Aşılar listesinde yer almıştır.

Sağlık ve kondüsyonları aşılamaya uygun bulunan 255 sahipsiz köpek rehabilitasyon sırasında proflaktik olarak Kuduz hastalığına karşı monovalan ve CPV, CDV, CAV-1 ve CAV-2, CPIV ve Leptospira spp. hastalıklarına karşı polivalan aşı ile aşılanmışlardır.

\section{Sonuç}

$\mathrm{Bu}$ çalışmada $\mathrm{CPV}, \mathrm{CDV}$ ve $\mathrm{CCoV}$ viral enfeksiyonlarınınsahipsiz köpeklerinde varlığı yanal akışlı lateral immünokramotografi yöntemi ile belirlenmiştir. $\mathrm{Bu}$ e-ISSN: 2148-2683 yöntem hasta başında çabuk sonuç vermesi, sahipsiz köpeklerin tabiatları gereği zabt-1 rabtın güç olduğu durumlarda ihtiyaç duyulan marazi maddenin kolay toplanabilmesi, deneysel süreçler içeren virüs izolasyonu, elektron mikroskobu, ELISA ve PCR yöntemlerine göre ulaşılabilir ve düşük maliyetli olması ve sonuçların okunması için teknolojik cihaz gerektirmemesi, oda sicaklıklarında saklanabilmeleri ve uzun raf ömürleri nedeniyle sahipsiz hayvan rehabilitasyon çalışmalarında avantaj sağlamaktadır. Yoon vd. [16] CCoV testlerinin yüksek hassasiyet ve özgünlükte olduklarını ve diğer CPV ve CDV antijen testleri ile çapraz reaksiyon vermediklerini bildirmiştir. Bu tür testlerin göreceli hızlılığı ve basitleştirilmesi, anında tedavi yanıtlarını kolaylaştırmaktadırlar. Barınaklardaki birden fazla etiyolojik ajanlı mix enfeksiyonlarda ekonomik ve hızlı sonuçları ile hastalık varlığını ortaya koyabilmeleri yönünden veteriner hekimler arasında giderek artan yaygınlıkta kullanılmaktadırlar. Hızlı viral enefeksiyon tanısının antibiyotik kullanımını azalttığ antibiyotik direnci ile kalıntı riskini azaltması nedeniyle olumlu etki yarattığı bildirlimiştir [51]. Çalışmanın sonuçlarına göre Yoon vd., [16] Buller vd., [51] ve Sen vd., [52] ile benzer şekilde testlerin Geçici Hayvan Barınaklarında sahipsiz köpek sağlığında kullanılmalarının faydalı olacağı düşünülmektedir.

$\mathrm{Bu}$ çalışmanın bulgularında sahipsiz köpekler arasında CPV, $\mathrm{CCoV}$ ve CDV prevalansı sirasiyla $\% 44,3, \% 19,8$ ve $\% 8,5$ olarak saptanmıştır. Köpeklerin 11 'de $(\% 10,4) \mathrm{CPV}$ ve $\mathrm{CCoV}$ koenfeksiyonu saptanmıştır.

Sen vd. [52] Bangladesh'te, Sakulwira vd. [53] Tyaland'da, Castanheira vd. [54] Yeşil Burun Adaların'da CPV prevalansını farklı yıllarda sirasiyla \%30, \%62,8 \%44,1 ve \%43,3olarak bulduklarını açıklamışlardır. Bu çalışmadaki bulgularımız \%44,3 ile Sen vd.'den [52] yüksek, Sakulwira vd.'den [53] düşük fakat Castanheira vd.'nin Castanheira vd. [54] farklı y1llardaki sonuçları ile benzerlikler göstermiştir. Öte yandan bulgularımız ile diğer araştırıcıların bulguları [52-54] prevalansın yaşla birlikte giderek azalmakta olduğu, en yüksek prevalansın 1-6 arasında olduğu ve erkeklerde $(\% 40,5)$, dişilerden $(\% 32,1)$ anlamlı olarak daha yüksek olduğu yönünde benzerlikler göstermiştir.

Ülkemizde yapılan çalışmalarda farklı araştırıcılar [56-62] CDV virüsünü köpekler arasında saptadıklarını ve virüsün dolaşımda dolaşımda olduğunu bildirmişlerdir. Koç vd. [57] H geninin dizi analizi ile yeni Türk dizilerinin Kuzey Kutbu benzeri soyda ayrılmış bir dizi oluşturduğunu belirlediklerini bildirmişlerdir. Gencay vd., [58] Türkiye'de ve Dorji vd. [55] Bhutan'da CDV prevalansını sirasıyla \%9,3 ve \%11,3 olarak, Castanheira vd. [54] Yeşil Burun Adaların'da farklı yıllarda \%0 ve \%11.3 olarak ve Headley vd., [59] ise Brezilya'da farklı bölgelerde $\% 7$ ila \% 66 arasında değişen oranlarda bulduklarını açıklamışlardır. Yılmaz vd. [60] yüksek pozitiflik bulduklarını ve izole ettikleri Türk CDV suşlarının aşı suşlarından bağımsız olduğunu ve Avrupa soyu ile daha yakından ilişkili olduğunu açıklamışlardır. Sahna vd. [62] inceledikleri örneklerde \%35,3 CPV ve CDV koenfeksiyonu saptadıklarını bildirmişlerdir Bulgularımız \% 8,5 prevalans ile vecinsiyetle ilişkili anlamlı bir fark olmaması ve 1 yaştan genç köpeklerde daha fazla görülmesiyle diğer çalışmalarla benzerlik göstermektedir.

Ülkemizde yapılan çalışmalarda Yeşilbağ vd. [20] RT-PCR ile \% 15,5 CCoV pozitifliği bulduklarını, Aktutay vd. [63] farklı genogruplardan $\mathrm{CCoV}$ suşlarının Türkiye'de dolaşımda olduğunu, Avcı vd. farklı çalışmalarda [64,65] \%24,4 ve \% 14,87 ve Gür vd. [66] \%96,5 seropozitiflik saptadıklarını 
açıklamışlardır. Çalışmada elde ettiğimiz bulgular \%19,8 CCoV pozitifliği ile benzerlikler göstermektedir. Farlılıkların ise test yöntemleri, örnekleme yapılan hayvanlar, çevre gibi faktörlere bağlı olabileceği düşünülmüştür.

Kuduz aşısı uygulaması zorunludur ve ilgili kanun ve yönetmelikler ile uygulanmaktadır ve yılda 1 defa zorunlu aşı tekrarı vardır. Günümüzde üretilen ve ülkemizde de kullanılan aşılar minimum 3 yıl koruma sağlamaktadır. Yapılması mutlaka önerilen aşıların, köpekleri sık görülen ciddi ve ölümcül hastalıklardan koruduğu için koşullar veya coğrafi konum ne olursa olsun tüm köpeklereuygulanması önerilmektedir. CPV enfeksiyonuülkemizde ve dünyada genç köpeklerde en s1k görülen bulaşıcı hastalık ve ölüm nedenlerinden birisidir. CPV, CDV, CAV-1 ve CAV-2, CPIV ve Leptospira spp. köpekler için mutlaka yaptırılması gereken aşılardır ve 3 hafta ara ile aşılanan köpeklerin minimum 3 yıl ve daha uzun süre koruma sağladıkları bilinmektedir. CPV, CDV, Adenovirüsler, CCoV'ün tür atlayabildikleri bilinmektedir.

Elbetteki aşılamanın tek bir doğrusu yoktur. Doğru aşılama Veteriner hekimin hastasını muayene ettikten sonra köpeğin yaşı, cinsi, yaşam tarzı, belirli bir coğrafi bölgedeki hastalık prevalansı, aşıya ulaşım kolaylığı pek çok hastaya özel faktörü gözden geçirdikten sonra planlaması gereken "Hastaya Özel" bir süreçtir. Bu nedenlerden ötürü, hiçbir standart aşılama politikası tüm olası durumları kapsamayabilir. Aşıların başlangıç yaşı ve tekrar aşılara arasında en uygun bekleme süreleri gibi temel kurallara uyulması gerekmektedir. Sahipsiz köpeklerin barınakta rehabilitasyon süresince kaldıkları geçici sürede Kuduz aşısının yanı sıra CPV, CDV, CAV-1, CAV-2, CPIV ve Laptospira spp., polivalan aşılarını da olduktan sonra geri bırakılmaları köpek populasyonu arasında profkasi sağlayacağı düşünülmektedir.

Türkiye'de sahipli köpek sayısı 1,220 milyon olarak tahmin edilmekte olup 2012-2021 arası dönemlerde köpek sayısı artış1 hızı \% 10,9 ile aynı dönemlerde \%10,6 olan insan nüfusu artış hızına paralel seyretmektedir ve artış göstermektedir [6, 7, 67]. Sahipsiz köpek sayısı hakkında anektodal bilgiler bulunmaktadır ve İstanbul'da 130.000 köpek olduğu tahmin edilmektedir [68]. Türkiye sahipsiz köpek yönetiminde 'Öldürme Yok, Yakalama Yok, Esaret Yok' insani politikası izlemektedir. Belediyeler bünyesinde geçici barındırma ve rehabilitasyon sağlanarak kısırlaştırma, kuduz aşısı, endo- ekto paraziter sağaltım ile hasta ve bakıma muhtaç hayvanların tedavisi sağlanmaktadır.

Sahipsiz ve serbest dolaşan köpekler, insan yerleşimlerinin bir parçası olmuşlardır ve çoğunlukla yaşamlarını insan atıklarından beslenerek sürdürmektedirler. Ortalama yaşam ömürleri kısa olup 0-5 yıl aras1 ve ortalama 3 y1l olarak bildirilmektedir ve yüksek ölüm oranları gözlenmektedir [70]. Paul vd. (2016) 5 y1l boyunca Hindistan'da Batı Bengal bölgesinde 7 farklı bölgede gözlemledikleri 364 yavru köpeğin sadece $\% 19$ 'unun $(n=70)$ üreme çağına kadar hayatta kaldığını gözlemlediklerini ve toplam ölümlerin \%63'ünün insan kaynaklı olduğunu saptadıklarını açıklamışlardır. Sahipsiz köpeklere uygulanacak proflaktik başlangıç aşıları olan Kuduz, CPV, CDV, CAV-1 ve CAV-2, CPIV ve Leptospira aşılarının kısa yaşam süreleri nedeniyle yaşam boyu koruma sağlayabileceği düşünülmektedir.

Bu çalışma sürecinde 12 aylık periyotta 296 sahipsiz köpek belirlendi ve rehabilitasyon uyguland1. 106 köpekte hastalık saptand1 ve klinik, hematolojik ve serolojik muayeneler yapilarak tedavi uyguland1. Bunlardan 77 'sinde $(\% 72,6)$ viral antijen saptandı ve köpeklerden 47'sinde (\%44,3) Canine e-ISSN: 2148-2683
Parvovirüs (CPV), 9'da (\%8,5) Canine Distemper Virüs (CDV), 21 'de $(\% 19,8)$ Canine Coronavirüs $(\mathrm{CCoV})$ ve 11 'de $(10,4)$ CPV ve CCoV koenfeksiyonu saptand. 255 köpek proflaktik olarak Kuduz, CPV, CDV, CAV-1 ve CAV-2, CPIV ile Leptospira spp, aşısı ile aşılandı. 400 endo- ve ektoparaziter uygulama yapıldı. 206 köpek küpeleme ve mikroçip ile kayıt altına alındı. 189 köpek kısırlaştırıldı ve 36 köpek sahiplendirildi.

\section{Teșekkür}

Bu proje T.C. Osmaniye Belediyesi ile Çukurova Üniversitesi Ceyhan Veteriner Fakültesi tarafından desteklenmiştir, teşekkür ederiz. Doğa, Yaban Hayatı Koruma ve Araştırma Derneği'ne projeye olan katkıları için teşekkür ederiz.

\section{Kaynakça}

Gompper, Matthew E. (2013). "The dog-human-wildlife interface: assessing the scope of the problem". In Gompper, Matthew E. (ed.). Free-Ranging Dogs and Wildlife Conservation. Oxford University Press. pp. 9-54. ISBN 9780191810183.

Lescureux, Nicolas; Linnell, John D.C. (2014). "Warring brothers: The complex interactions between wolves (Canis lupus) and dogs (Canis familiaris) in a conservation context". Biological Conservation. 171: 232-245. doi:10.1016/j.biocon.2014.01.032.

Lord, Kathryn; Feinstein, Mark; Smith, Bradley; Coppinger, Raymond (2013). "Variation in reproductive traits of members of the genus Canis with special attention to the domestic dog (Canis familiaris)". Behavioural Processe,. 92, 131-142. doi:10.1016/j.beproc.2012.10.009.

Slater, Margaret R (2001). "The role of veterinary epidemiology in the study of free-roaming dogs and cats". Preventive Veterinary Medicine. 48 (4): 273-86. doi:10.1016/S01675877(00)00201-4.

Høgåsen, H.R; Er, C; Di Nardo, A; Dalla Villa, P (2013). "Freeroaming dog populations: A cost-benefit model for different management options, applied to Abruzzo, Italy". Preventive Veterinary Medicine, 112 (3-4), 401-13. doi:10.1016/ j.prevetmed.2013.07.010.

Bedford, E. (2020). Global dog and cat pet population 2018. https://www.statista.com/statistics/1044386/dog-and-cat-petpopulation-worldwide/ Erişim Tarihi: 28.11.2021

Bedford, E. (2021). Number of dogs in Turkey 2012-2020. https://www.statista.com/statistics/515576/dog-populationeurope-turkey/

Headley S.A., Alfieri A.A., Fritzen J.T.T., Garcia J.L., Weissenböck H., Silva A.P., Bodnar 1., Okano W., Alfieri A.F. (2013). Concomitant canine distemper, infectious canine hepatitis, canine parvoviral enteritis, canine infectious tracheobronchitis, and toxoplasmosis in a puppy. Journal of Veterinary Diagnostic Investigation, Columbia, 25(1), 129-135.

Pratelli, A. (2005). Canine Coronavirus Infection. Recent Advances in Canine Infectious Diseases, by Charmichel, L. IVIS publications. 
Greene C.E., Vandevelde M. Canine distemper. In: Greene C.E. Infectious diseases of the dog and cat. 4th ed. St. Louis: Elsevier, p. 25-42, 2012.

Saraç, F. (2016). Canine Adenovirus Enfeksiyonları. Etlik Vet Mikrobiyol Derg,27 (2), 131-138.

Avcı, O., Bulut, O., Yapıcı, O., Şimşek, A., Hasırcıŏlu, S., Yavru, S., Kale, M., Dik, İ. \& Atlı, K. (2013). Investigation of Canine Parainfluenza Virus Type 2 in dogs by immunofluorescence. Eurasian Journal of Veterinary Sciences, 29(2), 87-91. Retrieved from https://dergipark. org.tr/tr/pub/eurasianjvetsci/issue/24807/262088

Wright, P.F., \& Webster, R.G., (2001). Orthomyxoviruses, In: Fields virology, Eds; Knipe DM, Howley PM, Lippincott Williams and Wilkins, Philadelphia, USA, pp; 1533-1579.

World Health Organization. "Rabies Fact Sheet N99". July 2013. https://www.who.int/news-room/factsheets/detail/rabies. Erişim Tarihi: 28.11.2021

Fu, Z.F. (2008). The rabies situation in Far East Asia. Dev Biol (Basel), 131, 55-61. PMID: 18634466.

Yoon, S. J., Seo, K. W., Song, K. H. (2018). Clinical evaluation of a rapid diagnostic test kit for detection of canine coronavirus. Korean Journal of Veterinary Research 58: 27-31.

Vlasova, A. N., Diaz, A., Damtie, D., Xiu, L., Teck-Hock Toh, Jeffrey Soon-Yit Lee, Linda J Saif, Gregory C Gray. (2021). Novel Canine Coronavirus Isolated from a Hospitalized Patient With Pneumonia in East Malaysia, Clinical Infectious Diseases, ciab456, https://doi.org/10.1093/cid/ ciab456.

Tortorici, M., Walls, A. C., Joshi, A., Park, Y-J., et al. (2021) Structure, receptor recognition and antigenicity of the human coronavirus CCoV-HuPn-2018 spike glycoprotein. bioRxiv preprint DOI:10.1101/2021.10.25.465646

Lednicky, J. A., Tagliamonte, M. S., White, S. K., Blohm, G. M., Alam, M. M., Iovine, N. M., Salemi, M., Mavian, C., \& Morris, J. G. (2021) Isolation of a Novel Recombinant Canine Coronavirus from a Visitor to Haiti: Further Evidence of Transmission of Coronaviruses of Zoonotic Origin to Humans. Clin Infect Dis. Oct 28:ciab924. doi: 10.1093/cid/ciab924. Epub ahead of print. PMID: 34718467.

Yeşilbağ, K., Yilmaz, Z., Torun, S., Pratelli, A. (2004). Canine coronavirus infection in Turkish dog population. Journal of veterinary medicine. $B$, Infectious diseases and veterinary public health, 51(7), 353-355. https://doi.org/10.1111/ j.1439-0450.2004.00773.x

Zappulli, V., Ferro, S., Bonsembiante, F., Brocca, G., Calore, A., Cavicchioli, L., Centelleghe, C., Corazzola, G., De Vreese S, Gelain ME, Mazzariol S, Moccia V, Rensi N, Sammarco A, Torrigiani F, Verin R, Castagnaro, M. (2020). Pathology of Coronavirus Infections: A Review of Lesions in Animals in the One-Health Perspective. Animals (Basel), 11;10(12):2377. doi: 10.3390/ani10122377. PMID: 33322366; PMCID: PMC7764021.

Vennema, H., Poland, A., Foley, J., \& Pedersen, N.C. Feline infectious peritonitis Virüses arise by mutation from endemic feline enteric coronaVirüses. Virology,243, 150-7, 1998. doi:10.1006/viro. 1998.9045.

Tekelioglu, B. K., Berriatua, E., Turan, N., Helps, C. R., Kocak, M., \& Yilmaz, H. (2015). A retrospective clinical and epidemiological study on feline coronavirus (FCoV) in cats in Istanbul, Turkey. Preventive veterinary medicine, 119(12), 41-47. https://doi.org/10.1016/j. prevetmed. 2015. 01. 017

Laude, H., van Reeth, K., \& Pensaert, M. (1993). Porcine respiratory coronaVirüs: molecular features and Virüs-host interactions. Vet Res, 24, 125-50.

Guan, Y., Zheng, B.J., He, Y.Q., Liu, X.L., Zhuang, Z.X., \& Cheung, C.L., et al. (2003). Isolation and characterization of Virüses related to the SARS coronaVirüs from animals in southern China. Science, 302, 276-278,. 10.1126/ science. 1087139 .

Erles, K., Toomey, C., Brooks, H.W., \& Brownlie. J. (2003). Detection of a group 2 coronaVirüs in dogs with canine infectious respiratory disease. Virology, 310, 216-223.

Buonavoglia, C., Decaro, N., Martella, V., Elia, G., Campolo, M., Desario, C., Castagnaro, M., \&Tempesta, M. (2006). Canine Coronavirus Highly Pathogenic for Dogs. Emerg Inf Dis, 12(3), 492-494,. doi:10.3201/eid1203.050839

Hoelzer, K.,\& Parrish, C.R. (2010). The emergence of parvoVirüses of carnivores. Vet Res. 41(6), 39. doi: 10.1051/vetres/2010011. Epub Feb 15. 2. 2.

Greene, C.E.,\& Decaro, N. (2012). Canine viral enteritis. In: Greene C.E. Infectious diseases of the dog and cat. 4th ed. St. Louis: Elsevier, 67-80.

Castro, T., Garcia, R.C.C., Gonçalves, P.S.L., Costa, E.M., Marcello C.G.G., Labarthe, V.N., \& Almeida, M.F. (2013). Clinical, hematological, and biochemical findings in puppies with coronavirus and parvovirus enteritis. Can Vet J., 54 (9), 885-888.

T.C. Osmaniye Mutlu Şehir (2015). https://osmaniyebld.gov.tr/mutlu-sehir-osmaniye.html Erişim Tarihi: 20.11.2021.

T.C. Osmaniye Belebiyesi Geçici Hayvan Barınma ve Rehabilitasyon Merkezi (2021). http://osmaniyebld.gov.tr/bolgenin-en-iyi-hayvan-barinagiosmaniyede.html. Erişim Tarihi: 20.11.2021

Mouzin, D.E., Lorenzen, M.J., Haworth, J,D., et al. 2004. Duration of serologic response to five viral antigens in dogs. J Am Vet Med Assoc, 224, 55-60.

Küçük Hayvan Veteriner Hekimler Derneği Aşı Rehberi. (2018). http://www.khvhd.org.tr/FileUpload/ds303192/File/ khvhd_ulusal_asi_rehberi.pdf. Erişim Tarihi: 20.11.2021.

Bohm, M., Thompson, H., Weir, A. et al. (2004) Serum antibody titres to canine parvovirus, adenovirus and distemper virus in dogs in the UK which had not been vaccinated for at least three years. Veterinary Record 154, 457-463

Mitchell, S. A., Zwijnenberg, R. J., Huang, J. et al. (2012) Duration of serological response to canine parvovirus-type 2 , canine distemper virus, canine adenovirus type 1 and canine parainfluenza virus in client-owned dogs in Australia. Australian Veterinary Journal 90, 468-473 
Mouzin, D. E., Lorenzen, M. J., Haworth, J. D. \& King, V. L. (2004) Duration of serologic serological response to five viral antigen in dogs. JAVMA, 224, 55-60.

World Health Organisation (WHO) ATCVet Index, live canine distemper virus + live canine adenovirus + live parainfluenza virus + live canine parvovirus + inactivated rabies + inactivated leptospira (2021). https:/www.whocc.no/ atcvet/ atcvet_index/?code=QI07AJ06 Erişim Tarihi: 10.11.2021.

World Health Organisation (WHO) ATCVet Index, Canine Coronavirus Vaccines. (2021). https://www.whocc.no/atcvet/atcvet_index/?code=QI07AD 11 Erişim Tarihi: 10.11.2021.

Brooks, W. (2021). Parvovirus: Caring for the Recovered Dog. https://veterinarypartner.vin.com/default.aspx?pid =19239 \&id=4951465. Erişim Tarihi: 20.11.2021.

Yasuhiro I., Kazuya N.,Takayuki M., Ming-Chu C.,Tzong-Fu K., James A. L., Takeshi M., Chieko K., Eiji T. Seroprevalence of Canine Distempervirüs in Cats. Clin Vaccine Immunol, 8 (3), 641-644. 2015. doi:10.1128/CDLI.8.3.641-644.2001.

Borkenhagen, L. K., Fieldhouse, J. K., Seto, D., \& Gray, G. C. (2019). Are adenoviruses zoonotic? A systematic review of the evidence. Emerging microbes \& infections, 8(1), 16791687. https://doi.org/10.1080/ 22221751.2019.1690953

Sykes, J. E. (2014). Canine Viral Respiratory Infections. Canine and Feline Infectious Diseases, 170-181. https://doi.org/10.1016/B978-1-4377-0795-3.00017-X

Lunn, K.L. (2021). Leptospirosis in Dogs. MSD Veterinary Manuel. https://www.msdvetmanual.com/generalizedconditions/leptospirosis/leptospirosis-in-dogs

Gültekin, G. (2021). 3 Soruda Akciğer Kist Hidatik Hastalığı. Türk Göğüs Cerrahisi Derneği. https://www.tged.org.tr/3soruda-akciger-kist-hidatik-hastaligi/. Erişim Tarihi: 20.11.2021.

Jacob, J.,\& Lorber, B. (2015). Diseases Transmitted by Man's Best Friend: The Dog. Microbiol Spectr, Aug;3(4). doi: 10.1128/microbiolspec.IOL5-0002-2015.PMID: 26350317.

3285 Sayılı Hayvan Sağlığı ve Zabıtası Kanunu Uygulama Yönetmeliği. 15.3.1989, No: 20109.

Kuduz Hastalığından Korunma Ve Kuduz Hastalığı İle Mücadele Yönetmeliği. Gıda, Tarım ve Hayvancılık Bakanlığından Resmi Gazete, 18. Ocak. 2012, Sayı 28177.

Day, M. J., Horzinek, M. C., Schultz, R. D., Squires, R. A., \& Vaccination Guidelines Group (VGG) of the World Small Animal Veterinary Association (WSAVA) (2016). WSAVA Guidelines for the vaccination of dogs and cats. The Journal of small animal practice, 57(1), 4-8. https://doi.org/10.1111/jsap.12431

Decaro, N., Buonavoglia, C., \& Barrs, V. R. (2020). Canine parvovirus vaccination and immunisation failures: Are we far from disease eradication?. Veterinary microbiology, 247, 108760. https://doi.org/10.1016/j.vetmic.2020.108760

Buller, H., Adam, K., Bard, A., Bruce, A., (Ray) Chan, K, W., Hinchliffe, S., Morgans, L., Rees, G., \& Reyher, K.K. (2020). Veterinary Diagnostic Practice and the Use of
Rapid Tests in Antimicrobial Stewardship on UK Livestock Farms. Frontiers in Veterinary Science, 7, 765-. DOI $=10.3389 /$ fvets. 2020.569545

Sen, S., Rahman, M.D., Nag, M., Rahman, M., Sarker, R., \& Kabir, S. M. L. (2016). Prevalence of canine parvovirus and canine influenza virus infection in dogs in Dhaka, Mymensingh, Feni and Chittagong districts of Bangladesh. Asian Journal of Medical and Biological Research.2. 138. 10.3329/ajmbr.v2i1.27579.

Sakulwira, K., Vanapongtipavorn, P., Theamboonlers, K., Oraveerakul, K., \& Poovorawan. Y. (2003). Prevalence of canine coronavirus and parvovirus infections in dogs with gastroenteritis in Thailand. Vet Med-Czech, 48, 163-167.

Castanheira, P., Duarte, A., \& Gil, S. et al. (2014). Molecular and serological surveillance of canine enteric viruses in stray dogs from Vila do Maio, Cape Verde. BMC Vet Res 10, 91. https://doi.org/10.1186/1746-6148-10-91

Dorji, T., Tenzin, T., \& Tenzin, K. et al. (2020)Seroprevalence and risk factors of canine distemper virus in the pet and stray dogs in Haa, western Bhutan. BMC Vet Res, 16, 135. https://doi.org/10.1186/s12917-020-02355-X

Ozkul, A., Sancak, A. A., Güngör, E., \& Burgu, I. (2004). Determination and phylogenetic analysis of canine distemper virus in dogs with nervous symptoms in Turkey. Acta veterinaria Hungarica,52(1), 125-132. https://doi.org/10.1556/AVet.52.2004.1.12

Koç, B. T., Akkutay-Yoldar, Z., \& Oğuzoğlu, T. Ç. (2021). New members to Arctic-like lineage of canine distemper virus from Turkey. Comparative immunology, microbiology and infectious diseases, 78, 101678. https://doi.org/10.1016/j.cimid.2021.101678

Gencay, G. A., Oncel, T., Karaoglu, Taner., Sancak, A.A., Demir A., A., \& Ozkul, A. (2004). Antibody prevalence to canine distemper virus (CDV) in stray dogs in Turkey. Revue de Medecine Veterinaire. 155. 432-434.

Headley, S.A., Amude, A.M. Alfieri, A.F., Bracarense A.P.F.R.L., \& Alfieri A.A. (2012). Epidemiological features and the neuropathological manifestations of Canine Distempervirüs induced infections in Brazil: a review. Semina: Ciências Agrárias, Londrina, 33, 5, 1945-1978,.

Yilmaz, V., Coşkun, N., Timurkan, M. O., Karakurt, E.,Nuhoğlu, Hilmi., Erkılıc, E., Kirmizigul, A., \& Sezer, M. (2022). The Investigation of Canine Distemper Virus in Different Diagnosis Materials of Dogs using Molecular and Pathological Methods, Northeastern Turkey. Indian Journal of Animal Research. 56. 1-7. 10.18805/IJAR.B-1389.

Hasırcıoğlu, S.,\& Aslım, H. (2021). Detecting canine distemper virus from ocular swab and blood samples of dogs by RealTime Rt-Pcr method. Kocatepe Veterinary Journal. $10.30607 / \mathrm{kvj} .963348$.

Sahna, K. \& Gencay Göksu, A. \& Atalay, O. (2008). Viral aetiology of diarrhoea in puppies from a same shelter in Turkey: Presence of mixed infections. Revue de Medecine Veterinaire, 159, 345-347.

Akkutay Yoldar, Z. , Koç, B. T. \& Oğuzoğlu, T. (2020). Phylogenetic analysis of partial transmembrane protein gene of canine coronaviruses detected in Turkey. Ankara 
Üniversitesi Veteriner Fakültesi Dergis , 67 (3) , 265-271 . DOI: 10.33988/auvfd.619074

Avci, O., Yavru1, S., Kale, M. \& Dik, I. (2015). Barınak köpeklerinde canine coronavirus varlığının belirlenmesi Eurasian J Vet Sci, 31, 3, 184-187.

Avci, O., Levent, O., Yapici, Orhan., Hasircioglu, S.,\&Simsek, A. (2016). Canine coronavirus infection in dogs in Turkey: Virologicaland serological evidence. Indian Journal of Animal Research. 50. 10.18805/ijar.11173.

Gür, S., Gençay, A., \& Doğan, N. (2008). A Serologic Investigation for Canine Corona Virus Infection in Individually Reared Dogs in Central Anatolia. J Fac Vet Med Univ Erciyes 5(2), 67-71.

Annual Population Growth Rate of Turkey (2021). https://data.tuik.gov.tr/Bulten/Index?p=The-Results-ofAddress-Based-Population-Registration-System-202037210\&dil=2İstanbul'daki sahipsiz kedi-köpek sayısı açıkland.

İstanbul'daki Sahipsiz Köpek Sayısı (2017). https://www.trthaber.com/haber/yasam/istanbuldakisahipsiz-kedi-kopek-sayisi-aciklandi-311559.html. Erişim Tarihi: 20.11 .2021

Uniyal, M. (2019). The Indian stray dog debate: Nobody is looking at the pets. Down to Earth. https://www.downtoearth.org.in/blog/governance/the-indianstray-dog-debate-nobody-is-looking-at-the-pets-65681.

Erişim Tarihi: 20.11.2021

Paul, M., Sen Majumder, S., Sau, S., Nandi, A. K., \& Bhadra, A. (2016). High early life mortality in free-ranging dogs is largely influenced by humans. Scientific reports, 6, 19641. https://doi.org/10.1038/srep19641 